\title{
The chronic effects of cyanide on oxidative stress indices in the domestic chicken (Gallus domesticus L.)
}

\author{
Helen Ejiro Kadiri ${ }^{*}$ (D) and Samuel Ogheneovo Asagba
}

\begin{abstract}
Background: This study was conducted in order to elucidate the effects of cyanide $\left(\mathrm{CN}^{-}\right)$as sodium cyanide on oxidative parameters in the tissues of birds (Gallus domesticus L.) exposed to $\mathrm{CN}^{-}$directly by gavage and indirectly through their feed.

Results: Lipid peroxidation (LPO) level and activities of catalase (CAT) and superoxide dismutase (SOD) were determined in the kidney, liver, heart, and brain of the $\left(C N^{-}\right)$exposed birds. LPO was significantly $(p<0.05)$ increased in a dose-dependent manner in all the tissues of birds exposed to $\mathrm{CN}^{-}$directly and indirectly (feed), while CAT and SOD activities were concomitantly decreased in a dose-dependent manner regardless of the mode of exposure. However, it is noteworthy that the effect of $\mathrm{CN}^{-}$was more pronounced in the tissues of birds administered $\left(\mathrm{CN}^{-}\right)$directly.

Conclusions: The study reveals that direct and indirect exposure of birds to $\mathrm{CN}^{-}$by gavage and food respectively induced oxidative stress. These findings were corroborated by the histopathological changes in the liver, kidney, and brain.
\end{abstract}

Keywords: Cyanide, Lipid peroxidation, Superoxide dismutase, Catalase

\section{Background}

The high and fluctuating cost as well as the availability of animal feed is one of the greatest problems in the livestock industries located in most developing countries. In addition, shortage of foreign currencies for importation and dwindling supply of conventional feed for use as raw materials have led to the search and use of alternative unconventional raw materials locally. (Tewe, 1994). One of such raw material that has been used locally in Nigeria is cassava, but the use of cassava as raw material in the feed industry has two major disadvantages or rather limitations and these include its low crude protein content of about 1-3\% (Badejo, 2018; Morgan \& Choct, 2016) and the synthesis and storage of cyanogenic glycosides present in its tuber. The toxicity of these cyanogenic glycosides has been attributed to their release of cyanide. (Adekanye, Ogunjimi, \& Ajala, 2013; Baghshani \& Ghodsi, 2016; Davis, 1981; Okoye \& Nwowo, 2017). Cyanide is a very deadly substance usually released on the hydrolysis of cyanogenic glycosides that cause death when ingested rapidly due to

\footnotetext{
*Correspondence: hekad@yahoo.com

Department of Biochemistry, Delta State University, Abraka, Nigeria
}

its ability to instigate cytotoxic hypoxia by inhibiting the mitochondrial enzyme cytochrome c oxidase which serves as the primary target area.

The death of birds from cyanide poisoning has been reported in many studies. Death has been known to occur through ingestion of cyanogenic plants as well as exposure to cyanide salts (Cooper, 2003; Hammel, 2011; Henny, Hallock, \& Hill, 1994; Laitos, 2013; Ma \& Pristos, 1997). Most of these studies however focussed on the acute and not the chronic effect of cyanide.

Studies have also shown that cyanide is a neurotoxin that stimulates intracellular generation of reactive oxygen species (ROS). Some of its biotoxic effects could be mediated through the attack of generative reactive oxygen species on some target organs such as the liver, kidney, heart, and brain. When the effects of free radicals are not mitigated in cells, oxidative stress occurs (He et al., 2017; Osawa, 2018). Some of the biomarkers of oxidative stress are catalase, malondialdehyde, and superoxide dismutase (Okolie \& Iroanya, 2003; Petkovic et al., 2018). However few studies exist on the ability of cyanide to induce oxidative stress in birds. Fewer still exist on the comparative toxic effect of cyanide in the tissues 
of birds when administered directly relative to when administered in their feeds. Thus, the present study assessed the toxic effect of varying doses of cyanide in the tissues of birds (Gallus domesticus L) when administered directly by gavage as compared to equivalent doses administered in their feed using known parameters of oxidative stress.

\section{Materials and methods}

\section{Animal procurement}

A total of 126, 1-day-old broiler birds (Gallus domesticus L) purchased from Zartech farms, Sapele, Delta State, Nigeria, were used for the study. The chicks were kept in a standard wooden cage made up of wire gauze net and solid woods. The chicks were fed with starter mash for 3 weeks, and thereafter, they were fed with grower mash; both mashes were purchased from Top feeds, PLC, Sapele, Delta State, Nigeria. The daily minimum and maximum temperatures were $22.56^{\circ} \mathrm{C}$ and $37.23^{\circ} \mathrm{C}$, respectively. The relative humidity was about $68 \%$ in the rainy season and about $25 \%$ in the dry season. The chicks were also given water ad-libitum.

\section{Sublethal studies}

The birds were divided into 7 groups of 18 birds each and given the following treatments. Birds in group I served as control and was given normal bird feed and water. Groups II-IV birds were intoxicated with 1, 2, and $3 \mathrm{mg} / \mathrm{CN}^{-} / \mathrm{kg}$ body weight as sodium cyanide $(\mathrm{NaCN})$ respectively every morning using gavage and fed with normal mash. Birds in groups V-VII were fed with 1 , 2, and $3 \mathrm{mg} \mathrm{CN} / \mathrm{kg}$ feed as $\mathrm{NaCN}$ respectively every morning. Forty-two birds (a third of the birds) in each group were given this treatment for 4 weeks, while 42 broiler birds were for 8 weeks. The final third in each group was treated for 12 weeks. Thus, each group had six birds each for the different duration of exposure.

\section{Collection of samples}

At the end of the duration specified $(4,8$, and 12 weeks) for each subgroup, chicks were weighed and sacrificed under anaesthesia: The liver, brain, heart, and kidney were collected after dissection and immediately used for biochemical analysis. All animal treatments were in accordance with the guidelines for laboratory animal care as contained in the NIH publication no. 85-93, revised 1985.

\section{Treatment of samples}

The tissues collected from the treated and control birds were weighed, and $20 \%$ homogenates were prepared using $10 \%$ sucrose solution. The homogenates were then centrifuged at a speed of $10,000 \times g$ for 15 min under cold conditions, and the supernatants obtained were used for biochemical analysis, according to the method of Tietz (1995).

\section{Principle \\ Biochemical assays}

The activity of superoxide dismutase (SOD) was assessed according to the method of Misra and Fridovich (1972), with 1 unit of the enzyme equivalent to the amount of enzyme needed for $50 \%$ inhibition of epinephrine in 1 minute. Assay for lipid peroxidation (LPO) was by the method of Gutterridge and Wilkins (1982). It was carried out by determining the amount of thiobarbituric acid reactive substance (TBARS) produced. Molar extinction value of $1.56 \times 10^{5} \mathrm{M} / \mathrm{cm}$ was used for the quantification, and this was expressed in terms of malondialdehyde (MDA) units/g/tissue. One unit represents $1 \mu \mathrm{mol}$ of MDA. In the determination of catalase activity in the tissues, the method of Cohen, Dembiec, and Marcus (1970) was adopted. The absorbance of each sample was read at $480 \mathrm{~nm}$ within $30-60 \mathrm{~s}$. The activity of catalase was given in $\mathrm{K} / \mathrm{min}$.

\section{Histopathological study}

Histopathological studies were carried out on the issues of the liver, brain, and kidney of control, and treated rats were fixed $10 \%$ neutral buffered formalin solution according to the method of Fischer et al. (2008).

\section{Statistical analysis}

The results were expressed as means \pm standard deviation. Data were compared using the one-way analysis of cariance (ANOVA). This was followed by students' $t$ test comparison between the different treated groups, and differences were considered to be statistically significant at $p<0.05$.

\section{Results}

Cyanide bioaccumulation in the liver, kidney, brain, and heart of birds exposed to cyanide directly by gavage and indirectly in their feed

The result in Table 1 showed the presence of $\mathrm{CN}^{-}$in all the organs of the birds in all the groups including the control birds at the end of each exposure interval. A dose-dependent increase in the level of cyanide was also observed in the organs of birds exposed to $\mathrm{CN}^{-}$directly and those given the $\mathrm{CN}^{-}$in their feed. However, there was a significantly higher $(p<0.05) \mathrm{CN}^{-}$concentration in all the organs of birds in the treated groups excluding group $\mathrm{V}$ (offered $1 \mathrm{mg} \mathrm{CN}^{-} / \mathrm{kg}$ feed) when compared with the control at the end of each exposure interval. Again, the $\mathrm{CN}^{-}$levels in the organs of birds given $\mathrm{CN}^{-}$ via food were lower than in birds given toxicant directly. The pattern of distribution of cyanide was also time dependent. At the end of the fourth week of exposure, we had kidney $>$ liver $>$ pancreas $>$ heart $>$ brain. At the 
Table 1 The bioaccumulation of cyanide in the organs of birds exposed to cyanide directly and indirectly in feed

\begin{tabular}{|c|c|c|c|c|c|c|c|}
\hline \multirow{2}{*}{$\begin{array}{l}\text { Groups } \\
\text { Organ }\end{array}$} & \multicolumn{3}{|c|}{ Direct exposure } & \multicolumn{4}{|c|}{ Exposure via food } \\
\hline & $\begin{array}{l}\text { Group I } \\
\text { (control) }\end{array}$ & $\begin{array}{l}\text { Group II (1 mg } \\
\mathrm{CN}^{-} / \mathrm{kg} \text { bwt) }\end{array}$ & $\begin{array}{l}\text { Group III (2 mg } \\
\mathrm{CN}^{-} / \mathrm{kg} \text { bwt) }\end{array}$ & $\begin{array}{l}\text { Group IV (3 mg } \\
\mathrm{CN}^{-} / \mathrm{kg} \text { bwt) }\end{array}$ & $\begin{array}{l}\text { Group V (1 mg } \\
C N^{-} / \mathrm{kg} \text { bwt) }\end{array}$ & $\begin{array}{l}\text { Group VI (2 mg } \\
\mathrm{CN}^{-} / \mathrm{kg} \mathrm{bwt)}\end{array}$ & $\begin{array}{l}\text { Group VII (3 mg } \\
\mathrm{CN}^{-} / \mathrm{kg} \text { bwt) }\end{array}$ \\
\hline \multicolumn{8}{|c|}{4 weeks exposure } \\
\hline Liver & $0.39 \pm 0.05^{a}$ & $1.80 \pm 0.05^{b}$ & $2.21 \pm 0.03^{c}$ & $3.12 \pm 0.07^{d}$ & $0.44 \pm 0.04^{a}$ & $0.69 \pm 0.05^{e}$ & $0.74 \pm 0.05^{f}$ \\
\hline Pancreas & $0.31 \pm 0.05^{\mathrm{a}}$ & $1.44 \pm 0.05^{b}$ & $1.85 \pm 0.04^{c}$ & $2.39 \pm 0.04^{d}$ & $0.37 \pm 0.05^{a}$ & $0.76 \pm 0.05^{\mathrm{e}}$ & $1.24 \pm 0.06^{f}$ \\
\hline Kidney & $0.36 \pm 0.05^{\mathrm{a}}$ & $2.13 \pm 0.05^{b}$ & $2.72 \pm 0.05^{c}$ & $3.15 \pm 0.08^{d}$ & $0.53 \pm 0.05^{\mathrm{a}}$ & $0.78 \pm 0.04^{e}$ & $1.17 \pm 0.05^{f}$ \\
\hline Brain & $0.29 \pm 0.05^{\mathrm{a}}$ & $0.86 \pm 0.05^{\mathrm{b}}$ & $1.60 \pm 0.04^{c}$ & $1.16 \pm 0.04^{d}$ & $0.38 \pm 0.05^{\mathrm{a}}$ & $0.69 \pm 0.05^{\mathrm{e}}$ & $0.86 \pm 0.07^{b}$ \\
\hline Heart & $0.28 \pm 0.03^{\mathrm{a}}$ & $0.95 \pm 0.04^{b}$ & $1.80 \pm 0.04^{c}$ & $2.45 \pm 0.04^{d}$ & $0.27 \pm 0.05^{\mathrm{a}}$ & $0.47 \pm 0.05^{\mathrm{e}}$ & $0.68 \pm 0.04^{f}$ \\
\hline \multicolumn{8}{|c|}{8 weeks exposure } \\
\hline Liver & $0.36 \pm 0.05^{\mathrm{a}}$ & $0.89 \pm 0.05^{b}$ & $1.71 \pm 0.05^{c}$ & $2.84 \pm 0.05^{d}$ & $0.32 \pm 0.05^{\mathrm{a}}$ & $0.53 \pm 0.05^{\mathrm{e}}$ & $0.89 \pm 0.05^{b}$ \\
\hline Pancreas & $0.32 \pm 0.05^{\mathrm{a}}$ & $0.74 \pm 0.05^{b}$ & $1.43 \pm 0.03^{c}$ & $2.78 \pm 0.04^{d}$ & $0.27 \pm 0.04^{\mathrm{a}}$ & $0.45 \pm 0.05^{\mathrm{e}}$ & $0.66 \pm 0.04^{f}$ \\
\hline Kidney & $0.48 \pm 0.03^{a}$ & $1.08 \pm 0.04^{b}$ & $2.27 \pm 0.04^{c}$ & $2.97 \pm 0.05^{d}$ & $0.44 \pm 0.04^{a}$ & $0.65 \pm 0.05^{e}$ & $1.06 \pm 0.05^{b}$ \\
\hline Brain & $0.33 \pm 0.05^{\mathrm{a}}$ & $0.79 \pm 0.04^{b}$ & $1.34 \pm 0.05^{c}$ & $1.46 \pm 0.04^{d}$ & $0.34 \pm 0.04^{\mathrm{a}}$ & $0.48 \pm 0.05^{\mathrm{e}}$ & $0.78 \pm 0.05^{b}$ \\
\hline Heart & $0.28 \pm 0.04^{a}$ & $0.84 \pm 0.05^{b}$ & $1.64 \pm 0.03^{c}$ & $2.63 \pm 0.04^{d}$ & $0.25 \pm 0.03^{\mathrm{a}}$ & $0.36 \pm 0.04^{e}$ & $0.76 \pm 0.05^{f}$ \\
\hline \multicolumn{8}{|c|}{12 weeks exposure } \\
\hline Liver & $0.19 \pm 0.04^{\mathrm{a}}$ & $0.46 \pm 0.04^{b}$ & $0.78 \pm 0.05^{c}$ & $1.07 \pm 0.05^{d}$ & $0.29 \pm 0.08^{\mathrm{a}}$ & $0.45 \pm 0.05^{b}$ & $0.62 \pm 0.06^{\mathrm{e}}$ \\
\hline Pancreas & $0.08 \pm 0.02^{\mathrm{a}}$ & $0.18 \pm 0.03^{b}$ & $0.30 \pm 0.05^{c}$ & $0.56 \pm 0.04^{d}$ & $0.09 \pm 0.05^{a}$ & $0.08 \pm 0.05^{\mathrm{a}}$ & $0.16 \pm 0.05^{b}$ \\
\hline Kidney & $0.22 \pm 0.02^{a}$ & $0.47 \pm 0.03^{b}$ & $0.90 \pm 0.05^{c}$ & $1.58 \pm 0.05^{d}$ & $0.37 \pm 0.06^{a}$ & $0.47 \pm 0.05^{b}$ & $0.87 \pm 0.06^{c}$ \\
\hline Brain & $0.17 \pm 0.05^{\mathrm{a}}$ & $0.25 \pm 0.03^{b}$ & $0.43 \pm 0.05^{c}$ & $0.67 \pm 0.05^{d}$ & $0.22 \pm 0.05^{\mathrm{a}}$ & $0.32 \pm 0.08^{b}$ & $0.47 \pm 0.05^{c}$ \\
\hline Heart & $0.12 \pm 0.07^{\mathrm{a}}$ & $0.41 \pm 0.02^{b}$ & $0.65 \pm 0.04^{c}$ & $0.78 \pm 0.05^{d}$ & $0.18 \pm 0.04^{a}$ & $0.27 \pm 0.05^{e}$ & $0.38 \pm 0.05^{b}$ \\
\hline
\end{tabular}

Means not sharing a common superscript $(a, b, c, d, e, f)$ on the same row differ significantly $(p<0.05)$ from each other. The results are expressed as mean \pm standard deviation $(n=6)$. The cyanide concentration is in micrograms per gram tissue for the organs and milligrams per milliter for the serum bwt body weight

end of the 8th week, we had kidney > liver > pancreas > heart > brain, and at the end of the 12th week, we had kidney $>$ liver $>$ heart $>$ brain $>$ pancreas, for those given cyanide directly. Birds given cyanide in their feed showed kidney $>$ liver $>$ brain $>$ heart $>$ pancreas at the end of the 12th week. The result indicated that the kidney had the highest bioaccumulation of cyanide irrespective of the time and mode of exposure, with the 12th week indicating the lowest bioaccumulation.

\section{Lipid peroxidation levels in the liver, kidney, heart, and brain of birds exposed to cyanide}

A significantly higher $(p<0.05)$ malondialdehyde (MDA) levels were recorded in all the treated groups except in group $\mathrm{V}\left(1 \mathrm{mg} \mathrm{CN}^{-} / \mathrm{kg}\right.$ feed), when compared with the control at the end of each exposure period (Table 2). Also, MDA levels of the respective organs of birds given $3 \mathrm{mg} \mathrm{CN}^{-} / \mathrm{kg}$ body weight (group IV) were significantly higher $(p<0.05)$ than that of birds administered lower doses of cyanide in vivo (groups II and III). Similarly, the MDA levels in the respective organs of birds given $3 \mathrm{mg}$ $\mathrm{CN}^{-} / \mathrm{kg}$ in feed (group VII) was significantly higher $(p<$ 0.05 ) than those of birds fed with lower cyanide in their diet (group V and VI) for each exposure period. Moreover, when compared, birds given $\mathrm{CN}^{-}$directly by gavage had higher levels of MDA than those exposed to cyanide via food. Thus, the study reveals that exposure of birds to $\mathrm{CN}^{-}$directly or via contaminated feed significantly increased the MDA level in a dose-dependent manner in the organs irrespective of the duration of exposure. However, the level of MDA is higher in birds treated with $\mathrm{CN}^{-}$directly than those administered with the toxicant through the feed.

\section{The activities of SOD in the liver, kidney, heart, and brain} of birds exposed to cyanide

SOD activity was present in all the organs of the birds in all the groups including the control birds at 4, 8, and 12 weeks of $\mathrm{CN}^{-}$exposure. However, significantly lower $(p$ $<0.05)$ SOD activities were recorded in all the treated groups except in groups II $\left(1 \mathrm{mg} \mathrm{CN}^{-} / \mathrm{kg}\right.$ bwt $)$ and $\mathrm{V}(1$ $\mathrm{mg} \mathrm{CN}^{-} / \mathrm{kg}$ feed), when compared with the control for each exposure period. Also, SOD activities of birds given $3 \mathrm{mg} \mathrm{CN} / \mathrm{kg}$ body weight directly and via food were significantly lower $(p>0.05)$ than those of birds given lower doses of $\mathrm{CN}^{-}$directly and via food respectively for each of the duration of exposure. In addition, when compared, those given $\mathrm{CN}^{-}$via feed had higher levels of SOD activities than those given the toxicant directly in most of the organs within the exposure periods (group II excluded). Thus, the study reveals that the activity of SOD in the tissue of $\mathrm{CN}^{-}$-exposed birds is influenced by 
Table 2 The level of lipid peroxidation (LPO) in some organs of birds exposed to cyanide directly and indirectly in feed

\begin{tabular}{|c|c|c|c|c|c|c|c|}
\hline \multirow{2}{*}{$\begin{array}{l}\text { Groups } \\
\text { Organ }\end{array}$} & \multicolumn{4}{|l|}{ Direct exposure } & \multicolumn{3}{|c|}{ Exposure via food } \\
\hline & I (control) & 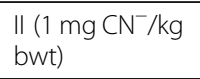 & $\begin{array}{l}\text { III ( } 2 \mathrm{mg} \mathrm{CN}^{-} / \mathrm{kg} \\
\text { bwt) }\end{array}$ & $\begin{array}{l}\text { IV (3 } \mathrm{mg} \mathrm{CN}^{-} / \mathrm{kg} \\
\text { bwt) }\end{array}$ & $\begin{array}{l}\mathrm{V}(1 \mathrm{mgCN}-/ \mathrm{kg} \\
\text { bwt) }\end{array}$ & 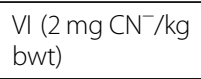 & $\begin{array}{l}\text { VII (3 } \mathrm{mg} \mathrm{CN}^{-} / \mathrm{kg} \\
\text { bwt) }\end{array}$ \\
\hline \multicolumn{8}{|c|}{4 weeks exposure } \\
\hline Liver & $323.54 \pm 15.9^{a}$ & $351.86 \pm 12.3^{b}$ & $494.35 \pm 18.9^{c}$ & $589.86 \pm 18.3^{d}$ & $335.02 \pm 7.1^{\mathrm{a}}$ & $382.74 \pm 9.2^{b}$ & $501.44 \pm 14.5^{c}$ \\
\hline Kidney & $202.49 \pm 9.4^{a}$ & $253.86 \pm 10.5^{b}$ & $356.08 \pm 13.6^{c}$ & $514.90 \pm 11.9^{d}$ & $227.55 \pm 12.3^{a}$ & $316.15 \pm 11.2^{b}$ & $412.05 \pm 15.4^{\mathrm{e}}$ \\
\hline Heart & $276.61 \pm 8.8^{\mathrm{a}}$ & $320.74 \pm 15.2^{b}$ & $421.62 \pm 18.1^{c}$ & $598.23 \pm 12.6^{d}$ & $299.08 \pm 15.9^{\mathrm{a}}$ & $375.14 \pm 22.1^{\mathrm{e}}$ & $477.64 \pm 23.2^{f}$ \\
\hline Brain & $266.99 \pm 10.7^{\mathrm{a}}$ & $316.07 \pm 11.8^{b}$ & $394.55 \pm 21.7^{c}$ & $568.75 \pm 22.6^{d}$ & $283.81 \pm 11.4^{a}$ & $365.63 \pm 13.2^{c}$ & $445.91 \pm 18.9^{e}$ \\
\hline \multicolumn{8}{|c|}{8 weeks exposure } \\
\hline Liver & $346.02 \pm 12.1^{a}$ & $401.15 \pm 19.4^{b}$ & $526.32 \pm 16.5^{c}$ & $647.32 \pm 18.9^{d}$ & $365.29 \pm 9.5^{\mathrm{a}}$ & $378.21 \pm 17.2^{a}$ & $505.12 \pm 18.1^{c}$ \\
\hline Kidney & $224.81 \pm 18.4^{a}$ & $303.51 \pm 16.2^{b}$ & $372.21 \pm 12.8^{c}$ & $468.80 \pm 17.5^{d}$ & $278.42 \pm 9.6^{b}$ & $322.12 \pm 14.5^{b}$ & $402.60 \pm 11.2^{c}$ \\
\hline Heart & $289.76 \pm 16.8^{\mathrm{a}}$ & $384.42 \pm 14.9^{b}$ & $499.54 \pm 11.5^{c}$ & $602.12 \pm 14.6^{d}$ & $299.36 \pm 15.5^{a}$ & $395.56 \pm 16.2^{b}$ & $489.02 \pm 22.7^{c}$ \\
\hline Brain & $277.43 \pm 11.2^{\mathrm{a}}$ & $357.02 \pm 13.8^{b}$ & $487.69 \pm 10.9^{c}$ & $584.24 \pm 23.8^{d}$ & $296.92 \pm 18.2^{\mathrm{a}}$ & $387.24 \pm 12.5^{b}$ & $465.28 \pm 18.5^{c}$ \\
\hline \multicolumn{8}{|c|}{12 weeks exposure } \\
\hline Liver & $357.28 \pm 11.5^{a}$ & $435.31 \pm 16.4^{b}$ & $561.44 \pm 21.6^{c}$ & $674.18 \pm 21.7^{d}$ & $381.14 \pm 13.4^{a}$ & $472.76 \pm 9.7^{e}$ & $564.13 \pm 15.6^{c}$ \\
\hline Kidney & $232.05 \pm 9.2^{a}$ & $327.16 \pm 12.8^{b}$ & $423.25 \pm 11.5^{c}$ & $482.23 \pm 10.9^{d}$ & $295.01 \pm 19.4^{\mathrm{e}}$ & $398.65 \pm 22.5^{f}$ & $453.74 \pm 12.8^{c}$ \\
\hline Heart & $301.51 \pm 13.6^{a}$ & $401.42 \pm 22.5^{b}$ & $534.67 \pm 13.9^{c}$ & $625.72 \pm 15.6^{d}$ & $352.45 \pm 11.7^{\mathrm{e}}$ & $445.91 \pm 13.4^{b}$ & $518.56 \pm 14.9^{c}$ \\
\hline Brain & $293.25 \pm 10.7^{\mathrm{a}}$ & $386.23 \pm 24.8^{b}$ & $507.90 \pm 14.8^{c}$ & $609.87 \pm 19.6^{d}$ & $314.34 \pm 12.6^{\mathrm{a}}$ & $412.15 \pm 17.5^{a}$ & $497.90 \pm 11.9^{c}$ \\
\hline
\end{tabular}

Means not sharing a common superscript $(a, b, c, d, e, f)$ on the same row differ significantly $(p<0.05)$

The results are expressed as mean \pm standard deviation $(n=6)$

Lipid peroxidation is expressed in units per gram tissue

bwt body weight

the mode of exposure. However, regardless of the mode of exposure to $\mathrm{CN}^{-}$, the activities of SOD were significantly decreased in a dose-dependent manner in the tissues of exposed birds relative to control (Table 3).

\section{Catalase activities in the liver, kidney, heart, and brain of birds exposed to cyanide}

Catalase activities were present in all the organs of the birds in all the groups including the control groups. However, significantly lower $(p<0.05)$ catalase activities were recorded in the groups exposed to 2 and $3 \mathrm{mg} \mathrm{CN}$ directly and indirectly (groups VI and VII) when compared with the control for each of the duration of exposure. Catalase activities in birds given $3 \mathrm{mg} \mathrm{CN}^{-} / \mathrm{kg}$ body weight (group IV) were significantly lower $(p<0.05)$ than those of birds given lower doses of $\mathrm{CN}^{-}$by the same mode (groups II and III) in all the organs for each of the duration of exposure. Similarly, catalase activities in the organs of birds given 2 and $3 \mathrm{mg} \mathrm{CN}^{-}$-tainted food (group VI and VII) were significantly lower $(p<$ $0.05)$ than those of birds exposed to $1 \mathrm{mg} \mathrm{CN}^{-}$in their diet (group V) for each of the duration of exposure. Also, like the case of SOD, the catalase activity of organs of birds fed with $\mathrm{CN}^{-}$-containing diet were significantly higher $(p<0.05)$ than those of birds treated with $\mathrm{CN}^{-}$ directly. Like SOD activity, the study shows that irrespective of the mode or duration of exposure, the activity of catalase was significantly decreased in the organs of cyanide-exposed birds when compared to the controls. However, the activity of catalase is influenced by the mode of exposure since the activity of the enzyme was lower in birds exposed to the toxicant directly than in those fed with $\mathrm{CN}^{-}$indirectly in the diet (Table 4).

\section{The effect of $\mathrm{CN}^{-}$on the histology of the organs of birds} The photomicrographs of the liver obtained from a bird in the control group (group 1) after 12 weeks of exposure are presented in Fig. 1. The result obtained shows normal hepatic cells (HC). Figure 2 shows the photomicrograph of a section of the liver obtained from a bird in the group IV at the end of 12 weeks of direct exposure to $3 \mathrm{mg} \mathrm{CN}^{-} \mathrm{kg}^{-1}$ body weight. It indicates the central vein $(\mathrm{CV})$, necrosis $(\mathrm{N})$, inflammation $(\mathrm{I})$, and bile duct proliferation (BDP). While that of the group VII birds

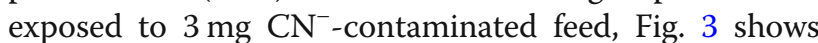
bile the duct proliferation (BDP), central vein congestion $(\mathrm{CVC})$, and necrosis $(\mathrm{N})$. No inflammation was found in the liver of birds exposed to cyanide indirectly.

Figure 4 shows the photomicrograph of the section of the kidney obtained from a bird in the control group at the end of 12 weeks. It showed normal cortical tubules (CT) and epithelial cells with glomerulus (G) in 
Table 3 The activity of superoxide dismutase (SOD) in some organs of birds exposed to cyanide directly and indirectly in their feed

\begin{tabular}{|c|c|c|c|c|c|c|c|}
\hline \multirow{2}{*}{$\begin{array}{l}\text { Groups } \\
\text { Organs }\end{array}$} & \multicolumn{5}{|c|}{ Direct exposure } & \multicolumn{2}{|l|}{$\begin{array}{l}\text { Exposure via } \\
\text { food }\end{array}$} \\
\hline & I (control) & $\begin{array}{l}\text { II (1 mg CN }{ }^{-1} / \mathrm{kg} \\
\text { bwt) }\end{array}$ & $\begin{array}{l}\text { III (2 } \mathrm{mg} \mathrm{CN}^{-1} / \mathrm{kg} \\
\text { bwt) }\end{array}$ & $\begin{array}{l}\text { IV (3 mg CN }{ }^{-1} / \mathrm{kg} \\
\text { bwt) }\end{array}$ & 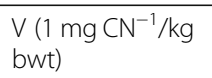 & $\begin{array}{l}\text { VI (2 mg CN }{ }^{-1} / \mathrm{kg} \\
\text { bwt) }\end{array}$ & $\begin{array}{l}\text { VII (3 mg CN }{ }^{-1} / \mathrm{kg} \\
\text { bwt) }\end{array}$ \\
\hline \multicolumn{8}{|c|}{4 weeks exposure } \\
\hline Liver & $43.46 \pm 0.8^{\mathrm{a}}$ & $37.25 \pm 0.6^{a}$ & $32.01 \pm 0.5^{b}$ & $23.07 \pm 0.3^{c}$ & $40.50 \pm 0.5^{\mathrm{a}}$ & $36.25 \pm 0.7^{\mathrm{a}}$ & $29.18 \pm 5^{b}$ \\
\hline Kidney & $31.10 \pm 0.4^{a}$ & $29.63 \pm 0.7^{a}$ & $18.52 \pm 0.3^{b}$ & $14.23 \pm 0.6^{b}$ & $30.74 \pm 0.4^{a}$ & $27.78 \pm 0.5^{a}$ & $17.67 \pm 3^{b}$ \\
\hline Heart & $35.32 \pm 0.7^{a}$ & $29.17 \pm 0.9^{a}$ & $25.10 \pm 0.4^{b}$ & $18.10 \pm 0.8^{c}$ & $33.34 \pm 0.6^{a}$ & $27.09 \pm 0.3^{a}$ & $22.92 \pm 4^{b}$ \\
\hline Brain & $31.24 \pm 0.5^{\mathrm{a}}$ & $30.01 \pm 0.4^{a}$ & $18.19 \pm 0.3^{b}$ & $14.10 \pm 0.9^{b}$ & $32.37 \pm 0.5^{\mathrm{a}}$ & $21.32 \pm 0.6^{b}$ & $18.48 \pm 3^{b}$ \\
\hline \multicolumn{8}{|c|}{8 weeks exposure } \\
\hline Liver & $45.14 \pm 0.8^{a}$ & $36.50 \pm 0.7^{\mathrm{ab}}$ & $34.52 \pm 0.6^{b}$ & $24.92 \pm 0.5^{c}$ & $38.15 \pm 0.6^{a}$ & $37.42 \pm 0.3^{b}$ & $28.10 \pm 0.6^{c}$ \\
\hline Kidney & $33.95 \pm 0.5^{a}$ & $25.93 \pm 0.6^{a}$ & $18.78 \pm 0.7^{b}$ & $12.15 \pm 0.6^{b}$ & $28.19 \pm 0.4^{a}$ & $26.08 \pm 0.4^{a}$ & $14.81 \pm 0.5^{b}$ \\
\hline Heart & $37.15 \pm 0.5^{\mathrm{a}}$ & $27.10 \pm 0.04^{b}$ & $23.12 \pm 0.4^{b}$ & $17.95 \pm 0.8^{b}$ & $31.25 \pm 0.7^{\mathrm{a}}$ & $25.74 \pm 0.6^{b}$ & $20.84 \pm 0.8^{b}$ \\
\hline Brain & $33.08 \pm 0.4^{a}$ & $25.10 \pm 0.5^{b}$ & $17.69 \pm 0.9^{c}$ & $13.95 \pm 0.3^{c}$ & $31.82 \pm 0.4^{a}$ & $20.46 \pm 0.3^{b}$ & $15.69 \pm 0.4^{c}$ \\
\hline \multicolumn{8}{|c|}{12 weeks exposure } \\
\hline Liver & $46.78 \pm 0.4^{\mathrm{a}}$ & $36.10 \pm 0.7^{b}$ & $30.43 \pm 0.8^{b}$ & $22.74 \pm 0.9^{c}$ & $42.62 \pm 0.4^{\mathrm{a}}$ & $32.18 \pm 0.6^{b}$ & $26.41 \pm 0.5^{c}$ \\
\hline Kidney & $34.15 \pm 0.9^{\mathrm{a}}$ & $27.78 \pm 0.4^{a}$ & $18.52 \pm 0.7^{b}$ & $11.26 \pm 0.9^{b}$ & $30.50 \pm 0.8^{a}$ & $24.19 \pm 0.8^{a}$ & $14.82 \pm 0.4^{b}$ \\
\hline Heart & $38.98 \pm 0.7^{\mathrm{a}}$ & $32.10 \pm 0.9^{\mathrm{a}}$ & $27.92 \pm 0.6^{b}$ & $15.87 \pm 0.8^{c}$ & $35.95 \pm 0.9^{\mathrm{a}}$ & $28.01 \pm 0.5^{b}$ & $18.75 \pm 0.3^{c}$ \\
\hline Brain & $35.04 \pm 0.8^{\mathrm{a}}$ & $31.73 \pm 0.5^{\mathrm{a}}$ & $25.92 \pm 0.6^{b}$ & $12.78 \pm 0.6^{c}$ & $34.52 \pm 0.7^{\mathrm{a}}$ & $19.92 \pm 0.5^{b c}$ & $15.75 \pm 0.8^{c}$ \\
\hline
\end{tabular}

Means not sharing a common superscript $(a, b, c)$ on the same row differ significantly $(p<0.05)$

The results are expressed as mean \pm standard deviation $(n=6)$

The activity of SOD is given in units per gram tissue

bwt body weight

Bowman's capsule. The photomicrograph of section of the kidney obtained from a bird in group IV at the end of 12 weeks of direct exposure to $3 \mathrm{mg} \mathrm{CN} \mathrm{kg}^{-1}$ body weight (Fig. 5) indicates tubular brush-border loss (TBL), necrosis of glomerulus (NG), and congestion of tubular cells (CTC). However, the photomicrograph of the kidney from a group VII bird at the end of 12 weeks of exposure to $3 \mathrm{mg} \mathrm{CN}^{-} / \mathrm{kg}$ feed (Fig. 6) showed that the glomera $(\mathrm{G})$ was loosely arranged in Bowman's capsule. There was also tubular brush-borders loss (TBL) and mild inflammation (MI).

The histopathological report of the brain of control rats is presented in Fig. 7. It showed that the tissues were normal in the control (group I) (at the end of 12 weeks). There were also normal neuronal cells (NC) and support (neuroglial) cells. The photomicrograph of the brain from a bird in group IV at the end of 12 weeks of direct exposure to $3 \mathrm{mg} \mathrm{CN}^{-} \mathrm{kg}^{-1}$ body weight (Fig. 8) showed the presence of neuronal cell congestion (NCC) and inflammatory cells (IC). However, the photomicrograph of the brain from a bird in group VII at the end of 12 weeks of exposure to 3

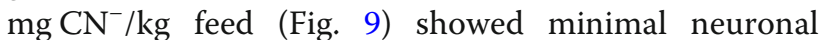
cell congestion (NCC) and no inflammation of cells was observed.

\section{Discussion}

The effects of cyanide and its distribution in the organs of the domestic chicken (Gallus domesticus) given different doses of cyanide directly and indirectly via diet were investigated in this study. The distribution of cyanide in the tissues of birds after the administration of different concentrations of cyanide for different periods of time by the two different methods (directly and via food) reveals that the accumulation and distribution of cyanide are influenced by time and mode of exposure (Table 1). This is in agreement with the works of Yamamoto, Yamamoto, and Hattori (1982). Among the organs investigated, the highest cyanide level was in the kidney irrespective of the mode and duration of exposure. High concentration of cyanide found in the kidney may be related to its role in metabolite elimination through the urate (Baghshani \& Aminlari, 2009). It has also been suggested from previous studies that the level of rhodanese in different tissues of animals is correlated with the level of exposure to cyanide (Abdelrahman \& Khogali, 2010; Aminlari, Gholami, Vaseghi, Azadi, \& Karimi, 2000; Eskandarzade, Aminlari, Golami, \& Tavana, 2012; Lewis, Rhoad, Gervasi, Griffith, \& Dahl, 1992). Therefore, the findings of this study are in agreement with that of Oh, Jalaludin, Davis, and Sykes (1977) who 
Table 4 The activity of catalase in some organs of birds exposed to cyanide directly and in their feed

\begin{tabular}{|c|c|c|c|c|c|c|c|}
\hline \multirow{2}{*}{$\begin{array}{l}\text { Groups } \\
\text { Organ }\end{array}$} & \multicolumn{4}{|c|}{ Direct exposure } & \multicolumn{3}{|l|}{ Exposure via food } \\
\hline & I (control) & $\begin{array}{l}\| \text { (1 } \mathrm{mg} \mathrm{CN}^{-1} / \mathrm{kg} \\
\text { bwt) }\end{array}$ & $\begin{array}{l}\text { III (2 } \mathrm{mg} \mathrm{CN}^{-1} / \mathrm{kg} \\
\text { bwt) }\end{array}$ & $\begin{array}{l}\text { IV (3 } \mathrm{mg} \mathrm{CN}^{-1} / \mathrm{kg} \\
\text { bwt) }\end{array}$ & 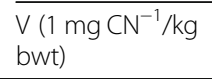 & 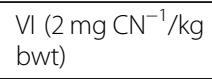 & $\begin{array}{l}\text { VII (3 mg CN }{ }^{-1} / \mathrm{kg} \\
\text { bwt })\end{array}$ \\
\hline \multicolumn{8}{|c|}{4 weeks exposure } \\
\hline Liver & $1.12 \pm 0.04^{a}$ & $0.98 \pm 0.06^{a}$ & $0.87 \pm 0.03^{b}$ & $0.75 \pm 0.09^{c}$ & $1.01 \pm 0.05^{\mathrm{a}}$ & $0.92 \pm 0.07^{a}$ & $0.83 \pm 0.09^{b}$ \\
\hline Kidney & $0.83 \pm 0.03^{\mathrm{a}}$ & $0.77 \pm 0.07^{\mathrm{a}}$ & $0.64 \pm 0.06^{b}$ & $0.54 \pm 0.08^{c}$ & $0.80 \pm 0.03^{\mathrm{a}}$ & $0.70 \pm 0.05^{\mathrm{ab}}$ & $0.61 \pm 0.08^{b}$ \\
\hline Heart & $1.05 \pm 0.07^{\mathrm{a}}$ & $0.94 \pm 0.09^{\mathrm{a}}$ & $0.82 \pm 0.07^{b}$ & $0.71 \pm 0.05^{c}$ & $0.98 \pm 0.09^{\mathrm{a}}$ & $0.85 \pm 0.03^{b}$ & $0.78 \pm 0.06^{b}$ \\
\hline Brain & $0.99 \pm 0.07^{\mathrm{a}}$ & $0.90 \pm 0.04^{a}$ & $0.79 \pm 0.05^{b}$ & $0.66 \pm 0.04^{c}$ & $0.92 \pm 0.08^{\mathrm{a}}$ & $0.81 \pm 0.06^{\mathrm{b}}$ & $0.76 \pm 0.03^{b}$ \\
\hline \multicolumn{8}{|c|}{8 weeks exposure } \\
\hline Liver & $1.28 \pm 0.02^{\mathrm{a}}$ & $1.22 \pm 0.07^{\mathrm{a}}$ & $1.08 \pm 0.06^{b}$ & $0.82 \pm 0.05^{c}$ & $1.24 \pm 0.06^{\mathrm{a}}$ & $1.14 \pm 0.03^{\mathrm{ab}}$ & $1.01 \pm 0.06^{b}$ \\
\hline Kidney & $0.94 \pm 0.08^{\mathrm{a}}$ & $0.89 \pm 0.06^{a}$ & $0.78 \pm 0.07^{b}$ & $0.60 \pm 0.06^{c}$ & $0.91 \pm 0.04^{a}$ & $0.81 \pm 0.04^{b}$ & $0.72 \pm 0.05^{b}$ \\
\hline Heart & $1.22 \pm 0.05^{\mathrm{a}}$ & $1.15 \pm 0.04^{a}$ & $0.95 \pm 0.04^{b}$ & $0.72 \pm 0.08^{c}$ & $1.18 \pm 0.07^{\mathrm{a}}$ & $0.97 \pm 0.06^{b}$ & $0.86 \pm 0.08^{b}$ \\
\hline Brain & $1.06 \pm 0.04^{\mathrm{a}}$ & $0.94 \pm 0.05^{b}$ & $0.83 \pm 0.09^{b}$ & $0.70 \pm 0.03^{c}$ & $1.00 \pm 0.04^{\mathrm{a}}$ & $0.91 \pm 0.03^{\mathrm{a}}$ & $0.80 \pm 0.04^{b}$ \\
\hline \multicolumn{8}{|c|}{12 weeks exposure } \\
\hline Liver & $1.31 \pm 0.04^{\mathrm{a}}$ & $1.24 \pm 0.07^{\mathrm{a}}$ & $1.13 \pm 0.08^{b}$ & $0.96 \pm 0.09^{c}$ & $1.26 \pm 0.04^{a}$ & $1.19 \pm 0.06^{b}$ & $1.06 \pm 0.12^{b}$ \\
\hline Kidney & $1.01 \pm 0.09^{\mathrm{a}}$ & $0.93 \pm 0.12^{a}$ & $0.83 \pm 0.07^{b}$ & $0.60 \pm 0.09^{c}$ & $0.99 \pm 0.08^{\mathrm{a}}$ & $0.90 \pm 0.08^{b}$ & $0.72 \pm 0.04^{d}$ \\
\hline Heart & $1.26 \pm 0.70^{\mathrm{a}}$ & $1.18 \pm 0.09^{\mathrm{a}}$ & $1.03 \pm 0.06^{b}$ & $0.81 \pm 0.08^{c}$ & $1.21 \pm 0.09^{\mathrm{a}}$ & $1.05 \pm 0.05^{b}$ & $0.90 \pm 0.10^{b}$ \\
\hline Brain & $1.19 \pm 0.08^{\mathrm{a}}$ & $1.12 \pm 0.05^{\mathrm{a}}$ & $0.99 \pm 0.06^{b}$ & $0.78 \pm 0.12^{c}$ & $1.14 \pm 0.07^{\mathrm{a}}$ & $1.03 \pm 0.05^{b}$ & $0.89 \pm 0.08^{b}$ \\
\hline
\end{tabular}

The results are expressed as mean \pm standard deviation $(n=6)$

Means not sharing a common superscript $(a, b, c, d)$ on the same row differ significantly $(p<0.05)$

The activity of catalase is given in $\mathrm{K} / \mathrm{min}$

bwt body weight

reported that rhodanese activity in the kidney is two times than that of the liver in chicken. Similar reports reveal that renal activity of rhodanese significantly $(p<$ 0.05 ) exceeds that of the liver in pigeon (Agboola, Fagbohunka, \& Adenuga, 2006; Al-Qarawi, Hassan, \& Badreldin, 2001), in ostrich (Eskandarzade et al., 2012), and in Japanese quail (Baghshani \& Aminlari, 2009). Okoh and Pitt (1982) also showed that radioactive cyanide was widely distributed, with the highest concentrations in the gastrointestinal tract, blood, kidneys, lungs, spleen, and liver in rats fed $\mathrm{KCN}$ in the diet at $77 \mu \mathrm{mol} /$ day (approximately $5.5 \mathrm{mg} / \mathrm{kg}$-day $\mathrm{CN}$ ) for 3 weeks and then injected intraperitoneally (i.p.) with radiolabeled $\mathrm{NaCN}$. Apart from the kidney, the organ with the highest concentration of cyanide after 12 weeks of exposure in vivo (Table 1) is the liver. The liver has been shown from previous studies to be the major site of cyanide metabolism and detoxification (Agboola et al., 2006; Al-qarawi et al., 2001; Aminlari \& Gilanpour, 1991; Drawbaugh \& Marrs, 1987). The high cyanide concentration of cyanide in the liver is likely due to the first-pass metabolism in the liver, after oral dosing and initial deposition at the portal of entry, following exposure.

The determination of the quantity of feed consumed by the birds would have certainly given an idea on the exact dose of cyanide consumed by the birds exposed to cyanide indirectly in the feed. However, the quantity of feed consumed by the birds indirectly exposed to cyanide in the feed was not determined. So, unlike birds exposed to cyanide directly into the stomach by gavage, the dose of cyanide available to birds exposed indirectly

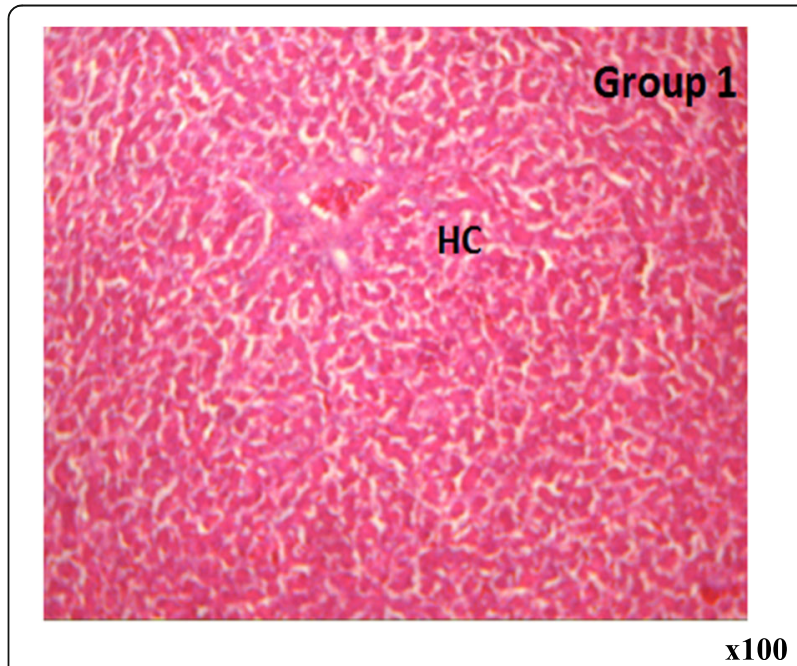

Fig. 1 Photomicrographs of the liver obtained from a bird in the control group. HC, hepatic cells 


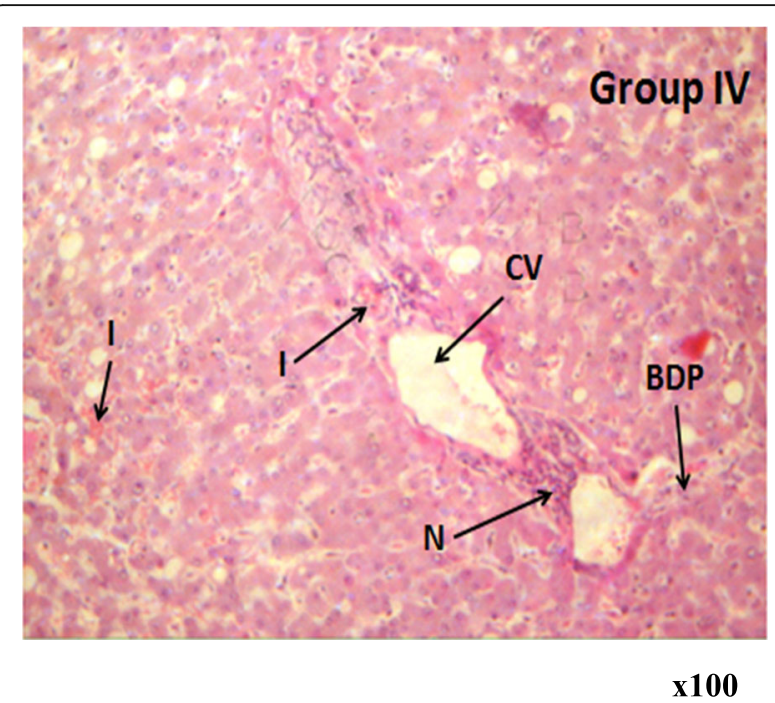

Fig. 2 Photomicrograph of the liver from a bird in group IV at the end of 12 weeks of direct exposure to $3 \mathrm{mg} \mathrm{CN} \mathrm{kg}^{-1}$ body weight. $\mathrm{CV}$, central vein; $\mathrm{N}$, necrosis; I, inflamation; $\mathrm{BDP}$, bile

duct proliferation

to cyanide in the feed is lacking. Therefore, the differences in the organ concentration of cyanide after both mode of exposures to the toxicant may be difficult to justify. Despite this omission, it is conceivable that the decreased concentration of cyanide in the organs of birds exposed to cyanide indirectly in the feed is attributable to the delay in absorption of the toxicant from the gastrointestinal tract occasioned by the binding of cyanide with compatible ligands in the feed. According to Amenorfe (2013), cyanide absorption is affected by

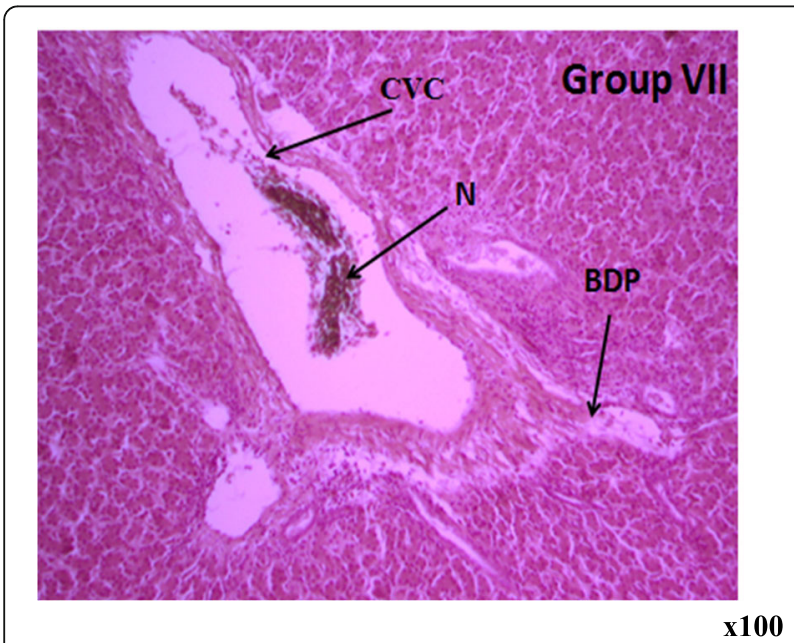

Fig. 3 Photomicrograph of the liver from a bird in group VII at the end of 12 weeks of direct exposure to $3 \mathrm{mg} \mathrm{CN} \mathrm{kg}^{-1}$ body weight. $\mathrm{BDP}$, bile duct proliferation; $\mathrm{CVC}$, central vein congestion; $\mathrm{N}$, necrosis

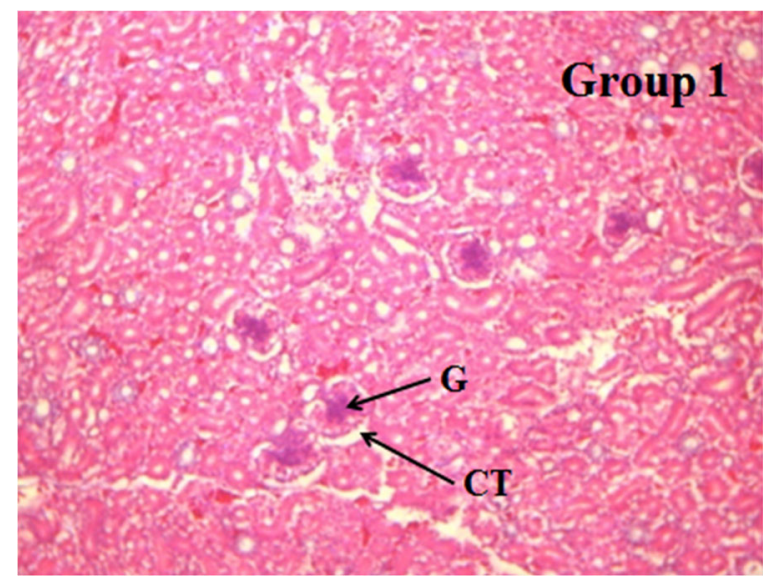

Kidney (x100)

Fig. 4 Photomicrographs of the kidney obtained from a bird in the control group. $\mathrm{CT}$, cortical tubule epithelial cells with glomerulus (G) in Bowman's capsule

the presence of food in the gut, the $\mathrm{pH}$ of the gut, and the lipid solubility of the cyanide compound.

The present study revealed that exposure to cyanide directly or by contaminated feed significantly increased the lipid peroxidation in all the organs but with the severest effect in the liver. Reactive oxygen species (ROS) are small, highly reactive, oxygen-containing molecules that can react with and damage complex cellular molecules, particularly in the liver (Wu \& Cederbaum, 2003). Cyanide has been shown from previous studies to induce oxidative stress by increasing reactive oxygen species and nitric oxide (Gunasekar, Sun, Kanthasamy, Borowitz, \& Isom, 1996; Mills, Gunasekar, Pavlakovic, \& Isom,

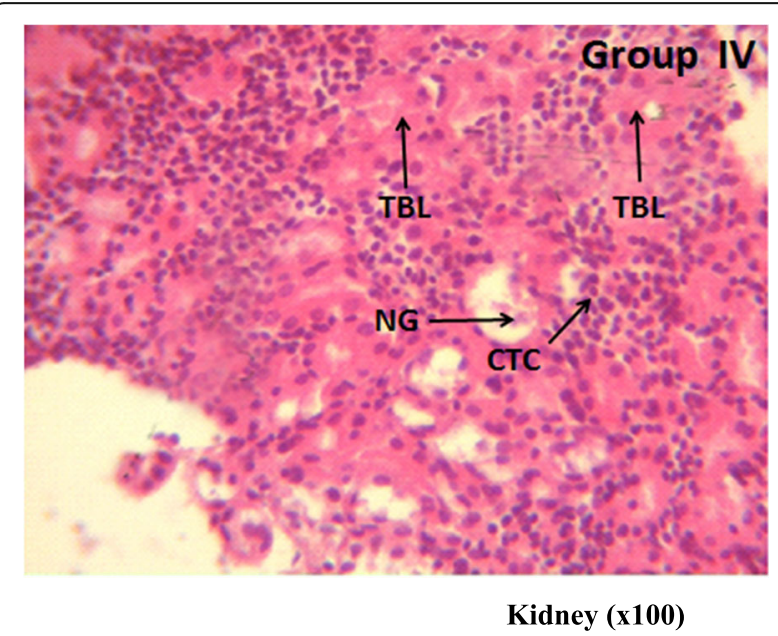

Fig. 5 Photomicrograph of the kidney from a bird in group IV at the end of 12 weeks of direct exposure to $3 \mathrm{mg} \mathrm{CN} \mathrm{kg}^{-1}$ body weight. TBL, tubular brush-border loss; NG, necrosis of glomerulus; CTC, congestion of tubular cells 


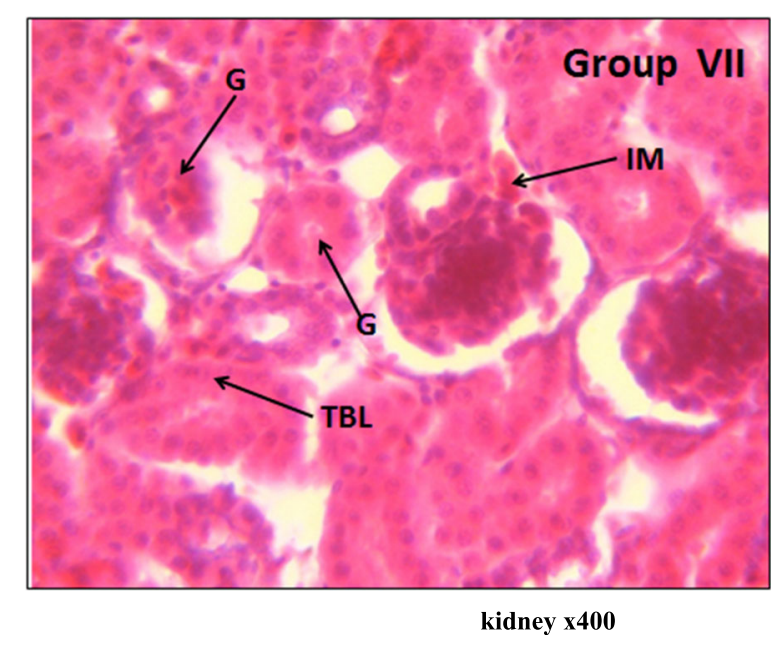

Fig. 6 Photomicrograph of the kidney from a bird in group VII at the end of 12 weeks of direct exposure to $3 \mathrm{mg} \mathrm{CN} \mathrm{kg}^{-1}$ body weight. G, glomera; TBL, tubular brush-border loss; IM, mild inflammation

1996) as well as the inhibition of antioxidant systems (Ardelt, Borowitz, \& Isom, 1989). Elevated levels of reactive oxygen species initiate lipid peroxidation (Frei, 1994; Val \& Almeida-Val, 1999) that culminates in oxidative stress in tissues (Halliwell, 1989, 1992; Liu \& Mori, 1994). An increase in lipid peroxidation has been reported for rats exposed to cyanide (Daya, Walker, \& KumarDukie, 2002). During the lipid peroxidation process, the activities of different membrane-bound enzymes are altered (Kukreja, Okabe, Schrier, \& Hess, 1988; Thomas \&

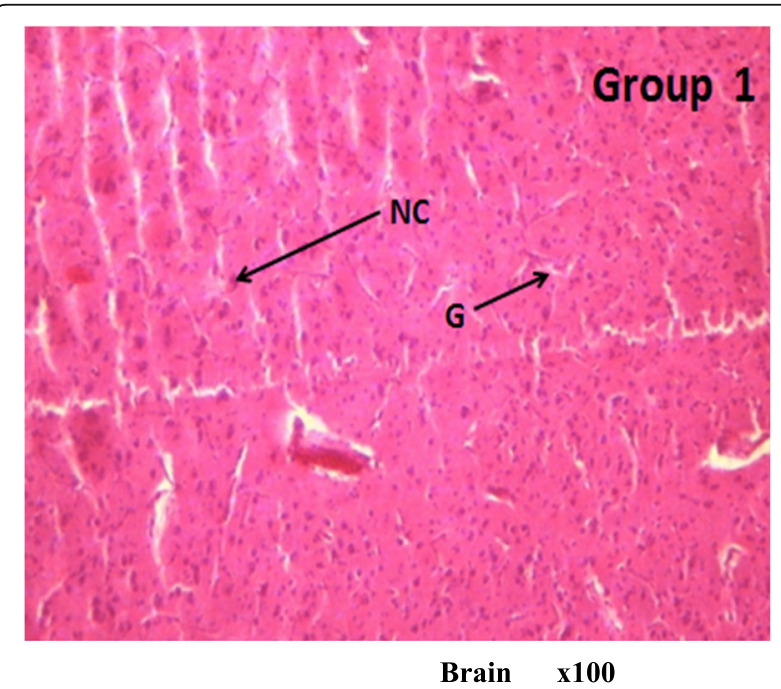

Fig. 7 Photomicrograph of the brain from a bird in group I (control) at the end of 12 weeks. NC neuronal cells; $G$, support (neuroglial) cells

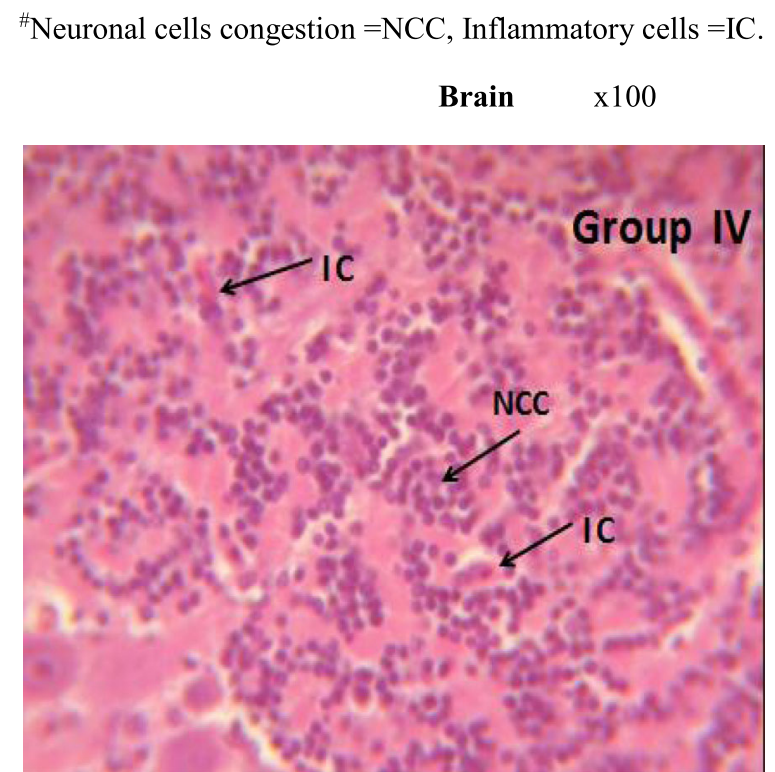

Fig. 8 Photomicrograph of the brain from a bird in group IV at the end of 12 weeks of direct exposure to $3 \mathrm{mg} \mathrm{CN} \mathrm{kg}^{-1}$ body weight. NCC, neuronal cell congestion; IC, inflammatory

Poznasky, 1990; Thomas \& Reed, 1990), resulting in the degeneration of cell membrane, (Nohl, 1993; Reiter, 1995), which predisposes the affected organisms to a wide array of disease processes (Morris, Earl, Trenam, \& Blake, 1995).

The results of the study had also shown that regardless of the mode of exposure to $\mathrm{CN}^{-}$, the activities of SOD and catalase were significantly decreased in the tissues of birds after 12 weeks of exposure (Tables 3 and 4) which may

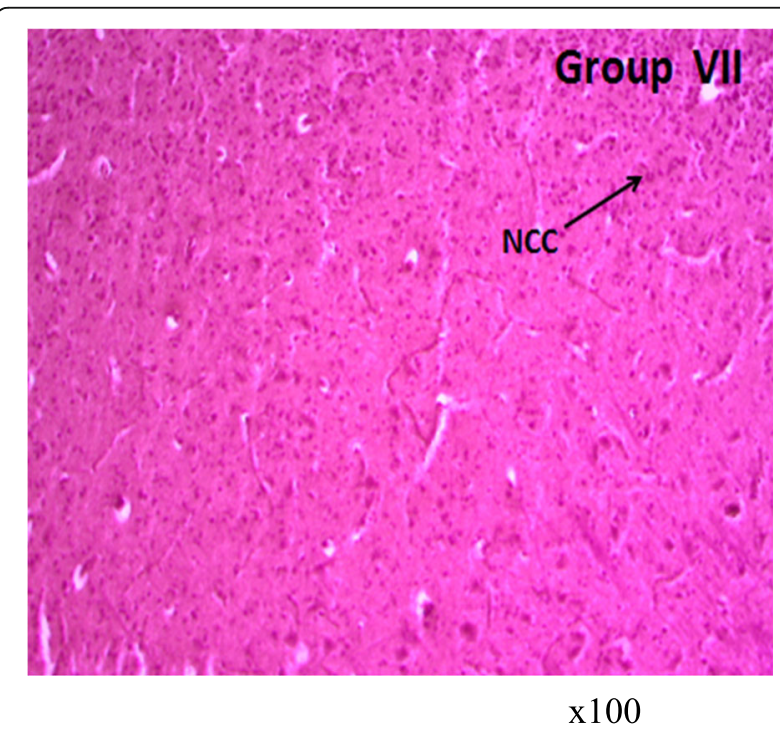

Fig. 9 Photomicrograph of the brain from a bird in group VII at the end of 12 weeks of direct exposure to $3 \mathrm{mg} \mathrm{CN} \mathrm{kg}^{-1}$ body weight. NCC, neuronal cell congestion 
account for the corresponding increase in lipid peroxidation. Though enhanced production of reactive oxygen species during stress can pose a threat to cells, animals have an in-built mechanism to counteract and scavenge the reactive oxygen species. The scavenging mechanisms include the presence of antioxidant enzymes: superoxide dismutase (SOD) and catalase. Under natural conditions, these internal antioxidant enzymes eliminate reactive oxygen species (ROS), providing protection for the cells. Damaging or inhibiting just one of these enzymes could significantly affect the defensive mechanisms. When an imbalance between free radicals and antioxidants occurs in favour of free radicals, an oxidative stress will be induced which can lead to chronic permanent damage (Halliwell, 1994). Increased generation of ROS has been implicated in the pathogenesis of several diseases and in the toxic effects of a wide variety of compounds (Halliwell \& Gutteridge, 1990). Decrease in the activity of SOD also portends reduction in the capacity of the birds to handle reactive oxygen species (Sasaki et al., 2008). Catalase is an important enzyme that protects a living system against oxidative stress, by scavenging hydrogen peroxide produced by superoxide dismutase. This it does by converting it to less-reactive gaseous oxygen and water molecules (Asada, 1992) and a reduction in the activity of this enzyme in the organs may be due to the inhibitory effect of cyanide on the enzyme. The concomitant decrease of SOD and catalase in the tissues of the cyanide-exposed birds confirms that both enzymes are linked functionally and as suggested by other investigators have shown that they work in tandem (Bartkowiak \& Barkowiak, 1981; Halliwell, 1994). Studies indicate that cyanide inhibition in the catalase reaction is noncompetitive even though cyanide competes with hydrogen peroxide for the same active site on the catalase molecule. (Boon, Downs, \& Marcey, 2007; Kertulis-Tartar, Rathinasabapathi, \& Ma, 2009; Ogura \& Yamazaki, 1983). This unusual feature may also apply to other enzymes such as the superoxide dismutase (Ogura \& Yamazaki, 1983). It is noteworthy that the effect of $\mathrm{CN}^{-}$was more pronounced in the tissues of birds administered $\left(\mathrm{CN}^{-}\right)$directly as compared to birds indirectly exposed to the toxicant in feeds. This finding is not unconnected to the higher levels of $\mathrm{CN}^{-}$in the organs of birds administered $\mathrm{CN}^{-}$directly relative to those administered the $\mathrm{CN}^{-}$-tainted feed.

The findings from the histological examinations of the organs are in harmony with the raised levels of lipid peroxidation and the corresponding decrease in the activities of antioxidant enzymes in cyanide exposed birds. According to Fulda, Galluzzi, and Kroemer (2010), it was shown that cells respond histopathologically to toxic insult by degeneration, proliferation, inflammation, and repair. The pathological changes in the organs of the $\mathrm{CN}^{-}$-exposed birds observed in the present study are in agreement with the prior study by David and Kartheek (2016) who reported $\mathrm{CN}^{-}$-induced pathological aberrations in the liver and kidney in the freshwater fish Cyprinus carpio following exposure to sublethal concentrations of sodium cyanide.

The results for the brain are also in agreement with previous studies that showed that oxidative stress is involved in cyanide-induced neurodegenerative diseases (Ardelt et al., 1989; Gunasekar et al., 1996; Bhattacharya et al., 1994).

\section{Conclusions}

In conclusion, the study reveals that direct and indirect exposure of birds to $\mathrm{CN}^{-}$by gavage and food respectively induced oxidative stress, but this effect was more pronounced in those exposed to the toxicant directly.

\section{Abbreviations}

BDP: Bile duct proliferation; Bwt: Body weight; CAT: Catalase; CN: Cyanide;

$C T$ : Cortical tubule epithelial cells; CV: Central vein; G: Glomerulus;

HC: Hepatic cells; I: Inflammation; LPO: Lipid peroxidation;

MDA: Malondialdehyde; MI: Mild inflammation; N: Necrosis; NC: Neuronal

cells; SOD: Superoxide dismutase; TBARS: Thiobarbituric acid reactive

substance; TBL: Tubular brush-border loss

\section{Acknowledgements}

We want to acknowledge Dr. Odokuma of the Department of Anatomy, Delta State University Abraka, Delta State, for helping us with the histological studies.

\section{Funding}

The authors declare that this work had no external funding.

\section{Availability of data and materials \\ All data used for this study will be made available on request by the corresponding author.}

\section{Authors' contributions}

HEK carried out the experiments under the supervision of SOA. HEK and SOA were both involved in the experimental design and conceptual framework. The write-up was done by HEK, and SOA carried out the technical and language check. Both authors have approved the submitted version of the work and have agreed to be personally accountable for the author's own contributions and ensure to both be personally accountable for the author's own contribution.

\section{Ethics approval and consent to participate}

Treatment of the birds was in accordance with the principles of Laboratory animal care $(\mathrm{NIH}, 1985)$.

\section{Consent for publication}

Not applicable

\section{Competing interests}

The authors declare that they have no competing interests.

\section{Publisher's Note}

Springer Nature remains neutral with regard to jurisdictional claims in published maps and institutional affiliations.

Received: 4 January 2019 Accepted: 3 April 2019

Published online: 03 May 2019

\section{References}

Abdelrahman, S. H., \& Khogali, S. M. E. (2010). Cyanide metabolizing enzymes in camels. Vetinary Research, 3(2), 29-31. 
Adekanye, T. A., Ogunjimi, S., \& Ajala, A. O. (2013). An assessment of cassava processing plants in Irepodun Local Government Area, Kwara State, Nigeria. World Journal of Agricultural Research, 1(1), 14-17.

Agboola, F. K., Fagbohunka, B. S., \& Adenuga, G. A. (2006). Activities of thiosulfate and 3-mercaptopyruvate sulfurtransferases in poultry birds and fruit bat. Journal of Biological Sciences, 6, 833-839.

Al-Qarawi, A. A., Hassan, M. M., \& Badreldin, H. A. (2001). Tissue and intracellular distribution of rhodanese and mercaptopyruvate sulfurtransferase in ruminants and birds. Vetinary Research Communication, 33, 63-70.

Amenorfe, P. L., (2013). Free and total cyanide in environmental samples from kenyase, a mining community in the Brong Ahafo region of Ghana. Thesis Submitted to the Department of Chemistry, Kwame Nkrumah University of Science.

Aminlari, M., Gholami, S., Vaseghi, T., Azadi, A., \& Karimi, H. (2000). Distribution of rhodanese in different parts of the urogenital systems of sheep at pre- and post-natal stages. Comparative Biochemistry Physiology Part B, 127, 369-374.

Aminlari, M., \& Gilanpour, H. (1991). Comparative studies on the distribution of rhodanese in different tissues of domestic chicken. Comparative Biochemistry Physiology Part B, 99, 673-677.

Ardelt, B. K., Borowitz, J. L., \& Isom, E. G. (1989). Brain lipid peroxidation and antioxidant protectant mechanisms following acute cyanide intoxication. Toxicology, 56, 147-154.

Asada, K. (1992). Ascorbate peroxidase a hydrogen peroxide scavenging enzyme in plants. Plant Physiology, 85, 235-241.

Badejo, A. A. (2018). Elevated carotenoids in staple crops: The biosynthesis, challenges and measures for target delivery. Journal of Genetic Engineering and Biotechnology, 16, 553-562.

Baghshani, H., \& Aminlari, M. (2009). Comparison of rhodanese distribution in different tissues of Japanese quail, partridge, and pigeon. Comparative Clinical Pathology, 18, 217-220.

Baghshani, H., \& Ghodsi, V. (2016). Evaluation of some enzymatic changes in the liver and kidney of rats following exposure to sublethal concentration of potassium cyanide. Iranian Journal of Toxicology, 10(4), 9-12.

Bartkowiak, A., \& Barkowiak, J. (1981). Superoxide dismutase and catalase activities in normal cancerous tissues. Comparative Biochemistry Physiology, 70b, 819-820.

Bhattacharya, R., Kumar, P. \& Sachan, A.S. (1994) Cyanide induced changes in dynamic pulmonary mechanics in rats. Indian Journal of Physiology and Pharmacology, 38(4),281-284.

Boon, E. M., Downs, A., \& Marcey, D. (2007). Proposed mechanism of catalase: $\mathrm{H}_{2} \mathrm{O}_{2}: \mathrm{H}_{2} \mathrm{O}_{2}$ oxidoreductase: catalase structural tutorial, (p. 02).

Cohen, G., Dembiec, D., \& Marcus, J. (1970). Measurement of catalase activity in tissue extracts. Annals of Biochemistry, 24, 30-38.

Cooper, R. (2003). The physiological effects of sub-lethal concentrations of cyanide on homing pigeons (Columba livia): a model system for migratory studies. MSc Thesis. University of Nevada, Reno.

David, M., \& Kartheek, R. M. (2016). In vivo studies on hepato-renal impairments in freshwater fish Cyprinus carpio following exposure to sublethal concentrations of sodium cyanide. Environmental Science and Pollution Research, 23(1), 722-733.

Davis, R. H. (1981). Cyanide detoxification in the domestic fowl. In B. Vennesland, E. E. Conn, C. J. Knowles, J. Wesley, \& F. Wissing (Eds.), Cyanide in biology, (pp. 51-60). New York: Academic Press.

Daya, S., Walker, R. B., \& Kumar-Dukie, S. (2002). Cyanide-induced free radical production in rat brain homogenate is reduced by aspirin. Metabolic Brain Disease, 15, 203-210.

Drawbaugh, R. B., \& Marrs, T. C. (1987). Interspecies differences in rhodanese (thiosulfate: cyanide sulfurtransferase, EC.2.8.1.1) activity in liver, kidney, and plasma. Comparative Biochemistry and Physiology Part B, 86, 307-310.

Eskandarzade, N., Aminlari, M., Golami, S., \& Tavana, M. (2012). Rhodanese activity in different tissues of the ostrich. British Poultry of Science, 53, 270-273.

Fischer, A. H., Jacobson, K. A., Rose, J., \& Zeller, R. (2008). Hematoxylin and eosin staining of tissue and cell sections. Cold Spring Harbor Protocols, 2008(5), pdb-prot4986.

Frei, B. (1994). Reactive oxygen species and antioxidant vitamins: mechanism of action. American Journal of Medicine, 97(suppl. 3A), 3A-55-3A-135.

Fulda, S., Galluzzi, L., \& Kroemer, G. (2010). Targeting mitochondria for cancer therapy. Nature Reviews Drug Discovery, 9, 447-464.

Gunasekar, P. G., Sun, P. W., Kanthasamy, A. G., Borowitz, J. L., \& Isom, G. E. (1996). Cyanide-induced neurotoxicity involves nitric oxide and reactive oxygen species generation after $\mathrm{N}$-methyl-D-aspartate receptor activation. Journal of Pharmacology and Experimental Therapeutics, 277, 150-155.

Gutterridge, J. M. C., \& Wilkins, C. (1982). Copper dependent hydroxyl radical damage to ascorbic acid. Formation of thiobarbituric acid reactive product. Febs Letters, 137, 327-340.

Halliwell, B. (1989). Oxidants and the central nervous system: some fundamental questions. Acta Neurologica Scandinavica, 126, 23-33.

Halliwell, B. (1994). Free radicals and antioxidants. A personal view. Nutrition Review, 52, 253-265.

Halliwell, B., \& Gutteridge, J. M. C. (1990). The antioxidant of human extracellular fluids. Archives of Biochemistry and Biophysics, 280, 1-8.

Hammel, J. (2011). A review of acute cyanide poisoning with a treatment update. Critical Care Nurse, 31(1), 72-82.

He, L., He, T., Farrarr, S., Ji, L., Liu, T., \& Ma, X. (2017). Antioxidants maintain cellular redox homeostasis by elimination of reactive oxygen species. Cell Physiology and Biochemistry, 44(2), 532-553.

Henny, C. J., Hallock, R., \& Hill, E. (1994). Cyanide and gold mines in Nevada USA. Ecotoxicology, 3, 45-58.

Kertulis-Tartar, G. M., Rathinasabapathi, B., \& Ma, L. Q. (2009). Characterization of glutathione reductase and catalase in the fronds of two Pteris ferns upon arsenic exposure. Plant Physiology and Biochemistry, 47(10), 960-965.

Kukreja, R. C., Okabe, E., Schrier, G. M., \& Hess, M. L. (1988). Oxygen radical mediated lipid peroxidation and inhibition of $\mathrm{Ca}^{2+} \mathrm{AT}$ Tase activity of cardiac sarcoplasmic reticulum. Archives of Biochemistry and Biophysics, 261, 447-457.

Laitos, J. G. (2013). Cyanide mining and the environment. Pace Environmental Law Review, 30(3), 869-876.

Lewis, J. L., Rhoad, C. E., Gervasi, P. G., Griffith, W. C., \& Dahl, A. R. (1992). The cyanide-metabolizing enzyme in human nasal respiratory mucosa. Toxicology and Applied Pharmacolology, 83, 101-107.

Liu, J., \& Mori, A. (1994). Involvement of reactive oxygen species in emotional stress: a hypothesis based on the immobilization stress induced oxidative damage and antioxidant defense changes in rat brain and the effect of antioxidant treatment with reduced glutathione lut. Journal of stress Management, 1, 249-263.

Ma, J., \& Pristos, C. A. (1997). Tissue specific bioenergetics effects and increased enzymatic activities following acute sub lethal and oral exposure to cyanide in mallard duck. Toxicology and Applied Pharmacology, 142, 297-302.

Mills, E. M., Gunasekar, P. G., Pavlakovic, G., \& Isom, G. E. (1996). Cyanide-induced apoptosis and oxidative stress in differentiated PC12 cells. Journal of Neurochemistry, 7, 1039-1046.

Misra, H. P., \& Fridovich, I. (1972). The role of superoxide anion in the autooxidation of epinephrine and a sample assay for superoxide dismutase. Journal of Biochemistry, 247, 3170-3175.

Morgan, N. K., \& Choct, M. (2016). Cassava: Nutrient composition and nutritive value in poultry diets. Animal Nutrition, 2, 253-261.

Morris, C. J., Earl, J. R., Trenam, C. W., \& Blake, D. R. (1995). Reactive oxygen species and iron- a dangerous partnership in inflammation. The International Journal of Biochemistry and Cell Biology, 27(2), 109-122.

$\mathrm{NIH}$ (1985). Principles of laboratory animal care. NIH publications no 85-93. Maryland: National Institute of Health, Betheseda.

Nohl, H. (1993). Invovement of free radicals in ageing: a consequence or a cause of senescence. British Medical Bulletin, 49, 653-667.

Ogura, Y., \& Yamazaki, I. (1983). Steady-state kinetics of the catalase reaction in the presence of cyanide. Journal of Biochemistry, 94(2), 403-408.

Oh, S. Y., Jalaludin, S., Davis, R. H., \& Sykes, A. H. (1977). The activity of avian rhodanese. British Poultry Science, 18, 385-389.

Okoh, P. N., \& Pitt, G. A. J. (1982). The metabolism of cyanide and gastrointestinal circulation of the resulting thiocyanate under conditions of chronic cyanide intake in the rats. Canadian Journal of Physiology and Pharmacology, 60, 381-386.

Okolie, N. P., \& Iroanya, C. U. (2003). Some histological and biochemical evidence for mitigation of cyanide-induced tissue lesions by antioxidant vitamin administration in rabbits. Food Chemistry and Toxicology, 41, 463-469.

Okoye, N. F., \& Nwowo, E. C. (2017). The amelioration of cyanide induced liver toxicity with bentonite using Wistar rat as experimental model. Journal of Applied Agriculture and Biotechnology, 14(1), 1-9.

Osawa, T. (2018). Development and application of oxidative stress biomarkers. Bioscience Biotechnology and Biochemistry, 82(4), 564-572.

Petkovic, A. M., Jakovljevic, V. L., Bradic, J. V., Jeremic, J. N., Jeremic, N. S., Nikolic Turnic, T. R., ... Zivkovic, V. I. (2018). The effects of potassium cyanide on the 
functional recovery of isolated rat hearts after ischemia and reperfusion: the role of oxidative stress. Oxidative Medicine and Cell Longevity, 2018, 1-11.

Reiter, R.J. (1995). Oxidative stressand antioxidant defense mechanisms in the ageing brain. FASEB Journal, 9,526-533.

Sasaki, T., Unno, K., Tahara, S., Shimada, A., Chiba, Y., Hoshino, M., \& Kaneko, T. (2008). Age-related increase of superoxide generation in the brains of mammals and birds. Aging Cell, 7(4), 459-469.

Tewe, O. O. (1994). Indices of cassava safety for livestock feeding. Acta Horticulture, 375, 241-249.

Thomas, C. E., \& Reed, D. J. (1990). Radical-induced inactivation of kidney $\mathrm{Na}^{+}$/ $\mathrm{K}^{+}$Atpase: sensitivity to membrane lipid peroxidation and protective effect of vitamin E. Archives of Biochemistry and Biophysics, 281, 96-105.

Thomas, D. P., \& Poznasky, M. J. (1990). Lipid peroxidation inactivates rat liver microsomal Glycerol-3-phosphate acyl transferase. Effect of iron and copper salt and carbon tetrachloride. The Journal of Biological Chemistry, 265, 2684-2691.

Tietz, N. W. (1995). Clinical guide to laboratory test, (3rd ed., pp. 518-519). Philadelphia: WB Saunders Company

Val, A. L., \& Almeida-Val, V. F. (1999). Effect of crude oil on respiratory aspect of some fish species of the Amazon. In A. L. Val, \& V. M. F. Almeida-Val (Eds.) Biology of Tropical fish Manaus, Brasil, (pp. 227-291).

Wu, D., \& Cederbaum, A. I. (2003). Alcohol, oxidative stress, and free radical damage. Alcohol Research \& Health, 27(4), 277-284.

Yamamoto, K., Yamamoto, Y., \& Hattori, H. (1982). Effects of routes of administration on the cyanide concentration distribution in the various organs of cyanide-intoxicated rats. Tohoku Journal of Experimental Medicine, 1137,7378 .

\section{Submit your manuscript to a SpringerOpen ${ }^{\circ}$ journal and benefit from:}

- Convenient online submission

- Rigorous peer review

- Open access: articles freely available online

- High visibility within the field

- Retaining the copyright to your article

Submit your next manuscript at $\boldsymbol{\nabla}$ springeropen.com 